\title{
ANALISIS PERKEMBANGAN FUNGSI INTERMEDIASI PERBANKAN SYARIAH DI PROVINSI JAWA TIMUR PERIODE TRIWULAN III 2008 - TRIWULAN III 2009
}

\author{
Oleh: \\ Fitriningsih Amalo \\ Mahasiwa Magister Manajemen Universitas Muhammadiyah Malang \\ E-mail/No. Hp: ithyamalo@yahoo.com/085649798911
}

\begin{abstract}
The research purpose are to find out intermediation function development of Syariah Banking in East Java Province (Three Months Period III 2008 - Three Months Period III 2009) and projecting or finding the intermediation function development trend of Syariah Banking in East Java Province (Three Months Period III 2008 - Three Months Period III 2009). The research kind was descriptive statistic. From the fund data to economic sector in East Java, Syariah Banking have not given special attention in funding the largest four sector in East Java, they were PHR, hotel and restaurant, farm, industry, and transportation-communication. For projection or intermediation function development, in each three months period it was developed, and some of them decreasing, that was funding from economic sector. The sectors were industry, construction, trading, and transportation. But it was only projection since everything could be changed in time according to the economic flow happened.
\end{abstract}

Keywords: development, intermediation, asset, and projection.

\section{PENDAHULUAN}

Selama tiga dasawarsa ekonomi Islam mengalami kemajuan yang pesat, baik dalam kajian akademis di perguruan tinggi maupun dalam praktek operasional. Dalam bentuk pengajaran, ekonomi Islam telah dikembangkan dibeberapa universitas baik dinegaranegara muslim, maupun non muslim, seperti Hongkong, USA, Inggris, China, Australia dan lain-lain. Sedangkan dalam bentuk praktek diwujudkan dengan lembaga keuangan seperti perbankan dan juga lembaga- lembaga ekonomi Syariah non Bank lainnya. Sampai saat ini, lembaga tersebut telah menyebar ke 75 negara termaksud ke negara barat.

Perkembangan Perbankan Syariah di Indonesia dimulai dari berdirinya Bank Muamalat Indonesia. Bank Syariah di Indonesia mendapatkan pijakan yang kokoh setelah adanya deregulasi sektor perbankan undang- undang (UU) No. 10 tahun 1998 yang telah mengatur secara terperinci landasan hukum serta jenisjenis usaha yang dapat dioperasikan dan diimplementasikan oleh Bank Syariah. Dalam UU tersebut juga mengarahkan pada Bank Konvesional untuk membuka unit- unit Syariah. Namun demikian, masih ada beberapa hal yang perlu disempurnakan antara lain perlunya penyusunan dan penyempurnaan ketentuan serta undang-undang operasional Bank Syariah secara tersendiri, sebab undang-undang yang telah ada sesungguhnya dasar hukum bagi penerapan dual banking system.

Dual banking system adalah terselenggaranya dua sistem Perbankan Konvensional dan Syariah secara berdampingan yang pelaksanaannya 
diatur dalam berbagai peraturan perundang-undangan yang berlaku. Sehingga yang terjadi adalah Bank Syariah tidak berdiri sendiri atau mandiri dalam operasionalisasinya di mana masih menginduk kepada Bank Konvensional. Bila demikian adanya Perbankan Syariah hanya menjadi salah satu bagian dari program pengembangan Bank Konvensional, padahal yang dikehendaki adalah Bank Syariah yang betul-betul mandiri dengan berbagai perangkatnya sebagai bagian perbankan yang diakui secara nasional. Maka Kini titik kulminasi telah tercapai dengan disahkannya UU No. 21 tahun 2008 tentang Perbankan Syariah.

Dengan adanya deregulasi yang semakin kuat, memberikan kesempatan yang seluas- luasnya bagi Perbankan Syariah di Indonesia untuk berkembang dan menjalankan fungsinya secara baik. Perbankan merupakan suatu sarana yang strategis dalam rangka pembangunan ekonomi, peran yang strategis tersebut terutama disebabkan oleh fungsi utama bank sebagai penghimpun dan penyalur dana dari masyarakat secara efektif dan efisien untuk mencapai tujuan pembangunan nasional.

Peran Perbankan Syariah dalam mendukung perekonomian nasional terus meningkat dari waktu kewaktu itu semua dapat dilihat dari total aset yang selalu tumbuh serta fungsi intermediasi yakni penghimpunan dana pihak ketiga dan pembiayaan yang disalurkan.

Krisis keuagan global yang menjadi petaka bagi semua negara didunia memiliki satu sisi yang membawa hikmah bagi perkembangan Perbankan Syariah. Perkembangan industri lembaga Syariah ini diharapkan mampu memperkuat stabilitas sistem keuangan nasional, dengan memaksimalkan fungsinya untuk menjembatani (lembaga intermediasi) antara pihak yang memiliki kelebihan dana dan pihak yang kekurangan/ membutuhkan dana baik untuk modal kerja ataupun konsumsi. Sehingga dapat diharapkan akan terjadi keseimbangan antara sektor moneter dan sektor rill.

Namun kondisi yang terjadi bahwa Perbankan Syariah dalam peran pemberian pembiayaan lebih terfokus kepada sektor konsumtif. Kabar bisnis (2009) mengabarkan bahwa Akad (kontrak) pembiayaan yang disalurkan oleh Perbankan Syariah secara nasional masih didominasi oleh Akad Murabahah yang mencapai Rp23 triliun atau 57,93\% dari total pembiayaan sebesar $\mathrm{Rp} 39,7$ triliun, terhitung sampai dengan April 2009. Kontribusi terbesar kedua disumbang oleh Akad Mudharabah, yaitu sebesar Rp8,3 triliun atau sekitar $20,9 \%$ dari total penyaluran pembiayaan Perbankan Syariah sampai dengan April 2009. Sedangkan Dalam Statistik Perbankan Indonesia (SPI) juga disebutkan bahwa pembiayaan dengan Akad Musyarakah mencapai Rp5,87 triliun atau sekitar $14,8 \%$ dari total pembiayaan. Sisanya, meliputi pembiayaan dengan akad Qardh, Ijarah, dan Istishna.

Melihat kondisi tersebut bahwa peran Perbankan Syariah untuk mengambangkan sektor rill belum maksimal. Padahal bila akad Mudharabah dan Musyarakah ditingkatkan akan menggairahkan sektor rill, Investasi meningkat, lapangan pekerjaan baru banyak tersedia sehingga pengangguran akan berkurang, kemiskinan menurun, pertumbuhan ekonomi meningktan dan akan mewujudkan tujuan pembangunan Indonesia yakni mensejahterakan masyarakat.

Informasi dari (http://kas.us/) menyatakan bahwa Kota Surabaya adalah ibukota Provinsi Jawa Timur, Indonesia. Surabaya merupakan kota terbesar kedua di Indonesia setelah 
Jakarta. Dengan jumlah penduduk metropolisnya yang mencapai 3 juta jiwa, Surabaya merupakan pusat bisnis, perdagangan, industri, dan pendidikan di kawasan Indonesia timur. Maka tidak mengherankan bila Pertumbuhan ekonomi Provinsi Jawa Timur selama triwulan pertama tahun 2009 mencapai $4,48 \%$, untuk pertama kalinya berhasil mengungguli angka pertumbuhan ekonomi nasional di periode yang sama sebesar 4,4\% (www.kapanlagi.com).

Salah satu sektor yang mendorong pertumbuhan ekonomi, adalah sektor keuangan. Dan Perbankan Syariah dewasa ini menunjukkan dedikasinya, untuk terus mengontrol fungsi dari Perbankan Syariah dalam mendorong pertumbuhan ekonomi khususnya disektor rill dengan melihat perkembangan pembiayaan yang diberikan. Apakah sektor konsumtif lebih tinggi atau produktif. Maka dirasa sangat perlu untuk selalu memantau perkembangan Perbankan Syariah dan juga memproyeksi apa yang akan terjadi. Apalagi Jawa Timur adalah provinsi yang besar dengan penduduk yang padat membutuhkan konsentrasi khusus dalam hal tersebut.

Berdasarkan gambaran di atas tujuan pada penelitian ini adalah untuk mengetahui bagaimana perkembangan fungsi intermediasi Perbankan Syariah di Provinsi Jawa Timur ( Periode Triwulan III 2008 : Triwulan III 2009), dan untuk mengetahui bagaimana Proyeksi atau trend perkembangan fungsi intermediasi Perbankan Syariah di Provinsi Jawa Timur ( Periode Triwulan IV 2009 : Triwulan IV 2010).

\section{TINJAUAN PUSTAKA}

Penelitian mengenai "Perbandingan antara Pembiayaan produktif dan konsumtif yang dikaitkan dengan Non Performing Financing pada Bank Perkreditan Rakyat Syariah (BPRS) di
NAD". Penelitian ini bertujuan untuk mengetahui seberapa besar (persentase) perbandingan antara pembiayaan produktif dan konsumtif yang dikaitkan dengan Non Performing Financing periode 2006 - 2007 dan untuk mengetahui Non Performing Financing cenderung terjadi pada pembiayaan produktif atau konsumtif.

Penelitian ini dilakukan pada Bank Perkreditan Rakyat Syari'ah (BPRS) Di NAD yang meliputi BPRS Hareukat Aceh Besar, BPRS Baiturrahman Aceh Besar, BPRS Hikmah Wakilah Banda Aceh, BPRS Rahmah Hijrah Agung Lhokseumawe, dan BPRS Tgk. Chik Dipante Sigli.

Hasil penelitian menunjukkan bahwa tingkat perbandingan Non Performing Financing (NPF) pada BPRS Di NAD pada tahun 2006 - 2007 sangat rendah, hal ini menggambarkan bahwa manajemen BPRS Di NAD telah berhasil untuk menurunkan tingkat pembiayaan bermasalah dan juga menunjukkan kualitas kredit yang baik dalam setiap pembiayaan yang disalurkan kepada nasabah.

Berdasarkan hasil penelitian diketahui bahwa rata- rata perbandingan Non Performing Financing (NPF) Pada BPRS Di NAD adalah persentase NPF yang dialami BPRS Rahmah Hijrah Agung Lhokseumawe untuk pembiayaan produktif tahun 2007 masih stabil sebesar 0,00003 \%, sedangkan pada BPRS Tgk. Chik Dipante Sigli tahun 2007 juga masih stabil sebesar 0,000001 \%. Pada BPRS Rahmah Hijrah Agung untuk pembiayaan konsumtif tahun 2007 mengalami kenaikan dari 0,0000001\% menjadi 0,0000009 \%, sedangkan pada BPRS Tgk. Chik Daipante tahun 2007 masih stabil sebesar 0,0000003\%. Sehingga hipotesis tidak terdapat perbedaan antara pembiayaan produktif dan konsumtif yang dikaitkan dengan Non Performing Financing. 
Berdasarkan analisa dan evaluasi yang dilakukan menunjukkan bahwa kolektibilitas pembiayaan yang meliputi lancar, kurang lancar, diragukan dan macet pada pembiayaan produktif dan konsumtif hanya dua BPRS yang memisahkan kolektibilitas pembiayaan tersebut yaitu BPRS Rahmah Hijrah Agung Lhokseumawe dan BPRS Tgk. Chik Dipante Sigli. Sedangkan pada BPRS Hareukat Aceh Besar, BPRS Baiturrahman Aceh Besar, dan BPRS Hikmah Wakilah Banda Aceh, pihak bank menggabungkan semua jenis kolektibilitas pembiayaan dalam menyusun laporan keuangan. Maka dari hasil analisa yang dilakukan terhadap kolektibilitas pembiayaan BPRS Di NAD dapat disimpulkan bahwa Non Performing Financing (NPF) cenderung terjadi pada pembiayaan produktif. Hal ini disebabkan karakter (kejujuran) dari nasabah, gagalnya usaha yang dijalaninya akibat persaingan bisnis, penyalahgunaan dana yang tidak semestinya, dan musibah bencana gempa dan tsunami. (www.wordprees.com)

Ada juga penelitian yang dilakukan oleh Hariati, Hendro Yudi (2008) tentang “ Analisa Perkembangan Perbankan Syariah Di Jawa Timur Selama Masa Krisis Ekonomi Di Indonesia Periode 1997 - 2003". Adapun hasil dari penelitian tersebut adalah kelima Bank Syariah diantaranya Bank Muamalat, BPRS Bakti makmur, BPRS Amanah Sejahtera, BPRS Daya Artha Mentari serta Bank Syariah Mandiri Cabang Surabaya tersebut dalam hal pembiayaan jenis pembiayaan Murrabahah yang paling diminati.

Dalam hal apapun pasti ada kendala maka dalam pelaksanaan penyaluran pembiayaan. Kendala tersebut adalah masalah teknis, kendala sumber daya manusia, kendala pemasaran dan kendala permodalan serta kendala mengahadapi pembiayaan bermasalah.

Untuk mengatasi kendalakendala tersebut adalah dengan memperluas jaringan, meningkatkan kualitas sumber daya manusia, usaha pemasaran produk dengan sosialisasi dan kerja sama dengan instansi dan Bank Syariah lainnya. Meningkatkan permodalan dilakukan dengan meningkatkan jumlah pemegang saham,kendala pembiayaan bermasalah dapat diatasi dengan meningkatkan kualitas SDM dalam menganalisis dan memelihara pembiayaan.

Temuan yang menarik lainnya adalah pada masa krisis ekonomi di Indonesia ternyata perkembangan Perbankan Syariah lebih baik dibandingkan perkembangan perbankan konvensional khususnya di Jawa Timur.

Sudarsono (2003) menyatakan bahwa fungsi dan peran Bank Syariah yang tercantum dalam pembukaan standar akuntansi yang dikeluarkan oleh AAOIFI (Accounting and Auditing Organization for Islamic Financial Institution) adalah Manajer investasi, Bank Syariah dapat mengelola investasi dana nasabah; Investor Bank Syariah, Bank Syariah dapat menginvestasikan dana yang dimiliki maupun dana nasabah yang dipercayakan kepadanya; Penyedia jasa keuangan dan lalu lintas pembayaran, bank syariah dapat melakukan kegiatan - kegiatan jasa jasa layanan perbankan sebagaimana lazimnya; Pelaksanaan kegiatan sosial sebagai ciri yang melekat pada entitas keuangan Syariah, bank Islam juga memiliki kewajiban untuk mengeluarkan dan mengelola (menghimpun, mengadministrasikan dan mendistribusikan) zakat serta dana - dana sosial lainnya.

Berdasarkan Peraturan Bank Indonesia Nomor: 62/24/PBI/2004 tanggal 14 Oktober 2004 tentang Bank 
Umum yang melaksanakan usaha berdasarkan prinsip Syariah, kegiatan usaha Bank Syariah adalah Penghimpunan dana (funding), Penyaluran dana atau pembiayaan (financing), dan Penyediaan jasa- jasa pelayanan perbankan (bank services).

\section{METODE PENELITIAN}

Jenis penelitian yang dilakukan yaitu penelitian Statistik deskriptif. Menurut Sugiyono (2009) Penelitian Statistik deskriptif adalah penelitian yang bertujuan untuk mendeskripsikan atau menggambarkan data yang telah terkumpul sebagaimana adanya tanpa bermaksud membuat kesimpulan yang berlaku untuk umum atau generalisasi.. Dalam hal ini penelitian yang dilaksanakan yakni penilaian terhadap Perkembangan Fungsi Intermediasi Perbankan Syariah di Propinsi Jawa Timur (Periode 2008 : 9 - 2009 : 9).

Dalam penelitian ini aspek perkembangan yang dilihat yakni fungsi intermediasi Perbankan Syariah yakni menghimpun dan menyalurkan dana

Data yang digunakan dalam penelitian ini adalah data sekunder yang merupakan data yang diperoleh secara tidak langsung dari obyek yang diteliti, dimana data laporan Perkembangan Perbankan di Jawa Timur Triwulan III 2009. Sumber data dalam penelitian ini didapat dari Laporan Perkembangan Bank Syariah di Jawa Timur yang terdapat dalam kajian Ekonomi Regional Jawa Timur Triwulan III 2009 yang diperoleh dari perpustakaan Bank Indonesia cabang Malang, dan sumber lain yang relevan dengan penelitian ini, seperti media cetak maupun media elektronik.

Penelitian ini berdasarkan hasil dari tinjauan lapangan dengan metode dokumentasi yaitu teknik pengumpulan data yang dilakukan dengan mencari dan mempelajari data dari laporan perkembangan Bank Syariah Triwulan III 2009 yang dikeluarkan oleh Bank Indonesia.

\section{PEMBAHASAN}

Secara umum kegiatan intermediasi perbankan yang terjadi di Jawa Timur sampai dengan triwulan III 2009 relatif berjalan lambat. Fungsi Intermediasi tersebut dapat dilihat pada kegiatan bank dalam menghimpun dana pihak ketiga dan pemberian pembiayaan kepada masyarakat.

Tabel 1. Perkembangan Total Aset, DPK, Pembiayaan

Periode triwulan III 2008 - triwulan III 2009 (dalam satuan jutaan)

\begin{tabular}{lccccc}
\hline \multicolumn{4}{c}{2008} & \multicolumn{3}{c}{2009} \\
\hline Total Aset & Tw III & Tw IV & Tw I & Tw II & Tw III \\
DPK & 3.014 .199 & 3.271 .828 & 3.631 .656 & 4.278 .696 & 4.369 .523 \\
Pembiayaan & 2.155 .819 & 2.527 .041 & 2.959 .175 & 3.507 .543 & 3.558 .948 \\
& 2.497 .399 & 2.549 .316 & 2.516 .204 & 2.909 .754 & 3.151 .113 \\
\hline
\end{tabular}

Sumber : Kajian Ekonomi Regional Jawa Timur Triwulan III-2009 


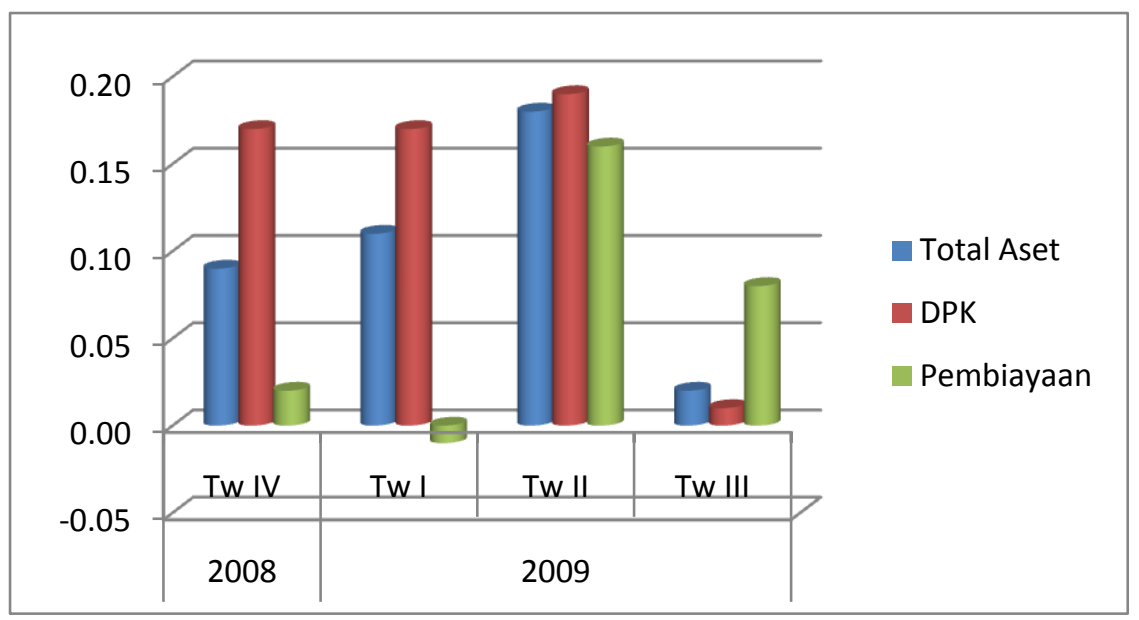

Gambar 1. Pertumbuhan Total Aset, DPK, Pembiayaan Periode triwulan III 2008 triwulan III 2009 (dalam persen)

Sumber: Kajian Ekonomi Regional Jawa Timur Triwulan III-2009, data diolah

Kondisi pertumbuhan dana pihak ketiga dan pembiayaan pada setiap triwulan menunjukkan sebuah perkembangan yang cukup baik. Pada Tw IV 2008 pertumbuhan DPK hanya mencapai 17\%, pada awal Tw I 2009 pertumbuhannya staqnan yakni sebesar $17 \%$, pada Tw II 2009 naik sebesar $2 \%$ menjadi $19 \%$. Namun pada Tw IV 2009 penurunan secara besar- besaran yakni dari $19 \%$ menjadi $1 \%$. Berbeda halnya dengan DPK, dimana bank menerima titipan dana dari nasabah maka sebagai follow up bank harus membalas jasa kepada masyarakat dengan melaksanakan fungsi penyaluran dana kepada mereka.

Pertumbuhan yang terjadi pada pembiayaan tidak terlalu mengecewakan, itu tergambar pada pertumbuhan yang cukup cepat yakni dari titik minus yang terjadi pada Tw I 2009 sebesar $(-1 \%)$, berubah mencapai titik plus yakni $16 \%$ pada Tw II 2009, ini merupakan prestasi yang baik bagi Bank Syariah karena telah berusaha semaksimal mungkin untuk bisa berperan di sektor pembiayaan, meskipun kembali menurun menjadi $8 \%$ pada Tw III 2009.
Pertumbuhan yang cukup fluktuatif, yang terjadi pada penghimpunan DPK, dan penyaluran dana (financing), berpengaruh pada pertumbuhan total Aset Perbankan Syariah di Jawa Timur. Pertumbuhan Total Aset Tw III 2008 - Tw III 2009 cukup baik karena selalu tumbuh meskipun lambat, dan jumlah total Aset Tw II 2008 sebesar Rp. 3,014 triliun menjadi Rp. 4,369 triliun pada Tw III 2009.

Dana Pihak Ketiga merupaka salah satu sumber permodalan bank yakni dari nasabah. Menurut Muhammad (2002), sumber utama modal Bank Syari'ah adalah modal inti (core capital) dan kuasai ekuitas. Modal inti adalah modal yang berasal dari para pemilik bank, yang terdiri dari modal yang disetor oleh para pemegang saham, cadangan dan laba ditahan. Sedangkan Ekuitas adalah dana- dana yang tercatat dalam rekeningrekening bagi hasil. Maka DPK sangat penting bagi sebuah bank.

Dalam Perbankan Syariah penghimpunan dana, dikenal 3 bentuk yakni Giro berdasarkan prinsip $A l$ Wadi'ah, Tabungan berdasarkan prinsip Al- Wadi'ah dan atau Al-Mudharabah, 
serta Deposito Berjangka berdasarkan prinsip Al-Mudharabah. Perkembangan ketiga bentuk DPK pada periode

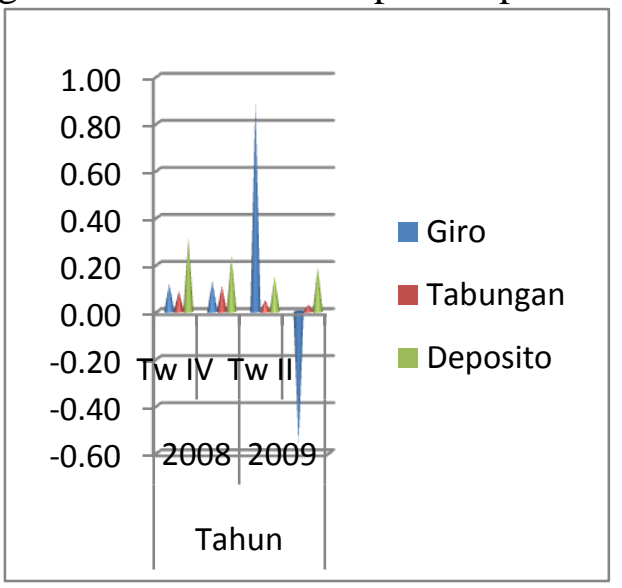

Gambar 2. Pertumbuhan Giro, Tabungan, dan Deposito Periode triwulan III 2008 - triwulan III 2009 (dalam satuan persen)

Sumber : Kajian Ekonomi Regional Jawa Timur

Triwulan III-2009, data diolah

Seperti yang telah diutarakan sebelumnya bahwa pertumbuhan DPK cenderung melambat, dan ternyata tidak semua terjadi pada ketiga bentuk penghimpunan dana. Penghimpunan dana dalam bentuk giro sangat baik pertumbuhannya itu terlihat pada Tw II 2009 yakni sebesar $89 \%$ ini angka yang sangat memuaskan, namun benar seperti teori segitiga sama kaki. Apabila cepat naiknya maka akan cepat pula turunnya, ini terbukti pada Tw berikutnya yakni Tw III 2009 penghimpunan dana dalam bentuk giro mengalami penurunan sampai ketitik minus di point $(-56 \%)$. Asumsi dari peneliti bahwa pada Tw III 2009 adalah musim lebaran, dan cenderung yang memiliki simpanan dalam bentuk giro adalah nasabah yang memiliki pendapatan menengah keatas jadi pada saat lebaran, nasabah serentak mengambil dananya.

Bentuk penghimpunan yang lain yakni tabungan cenderung menurun dari waktu ke waktu, kondisi ini sangat wajar terjadi karena tabungan adalah bentuk penghimpunan dana yang sewaktuwaktu bisa dipergunakan oleh nasabah, triwulan III 2008 - triwulan III 2009 dapat dilihat pada grafik dibawah ini :

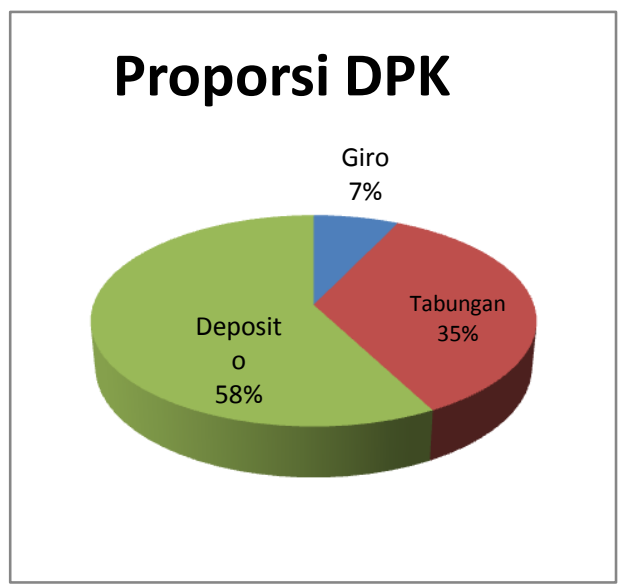

Gambar 3. Proporsi Giro, Tabungan, dan Deposito Periode triwulan III 2009 (dalam satuan persen)

Sumber : Kajian Ekonomi Regional Jawa Timur Triwulan III-2009, data diolah

angka pertumbuhan pada Tw IV 2008 sebesar 9\%, Tw I 2009; 11\%, Tw II 2009 ; $5 \%$ dan Tw III 2009; $3 \%$. Tidak jauh berbeda dengan bentuk penghimpunan yang terakhir yakni deposito cenderung menurun, namun tumbuh dengan lambat pada Tw III 2009 yakni sebesar $19 \%$.

Dari ketiga bentuk penghimpunan tersebut diatas yang menempati peringkat 1 dalam proporsi penghimpunan dana yang sangat diminati masyarakat yakni deposito sebesar $58 \%$, di ikuti tabungan sebesar $35 \%$ dan posisi terakhir ditempati oleh giro sebesar $7 \%$.

Peran pokok lembaga pembiayaan dalam hal ini bank termaksud didalamnya, yakni menghimpun dana dari masyarakat dan menyalurkannya kepada masyarakat yang sedang memerlukan, sehingga dari pernyataan tadi bisa diambil sebuah point bahwa peranan pembiayaan menjadi sangat penting. Pemberian pembiayaan juga merupakan eksistensi bank untuk terus menumbuhkan kepercayaan nasabah pada mereka. 


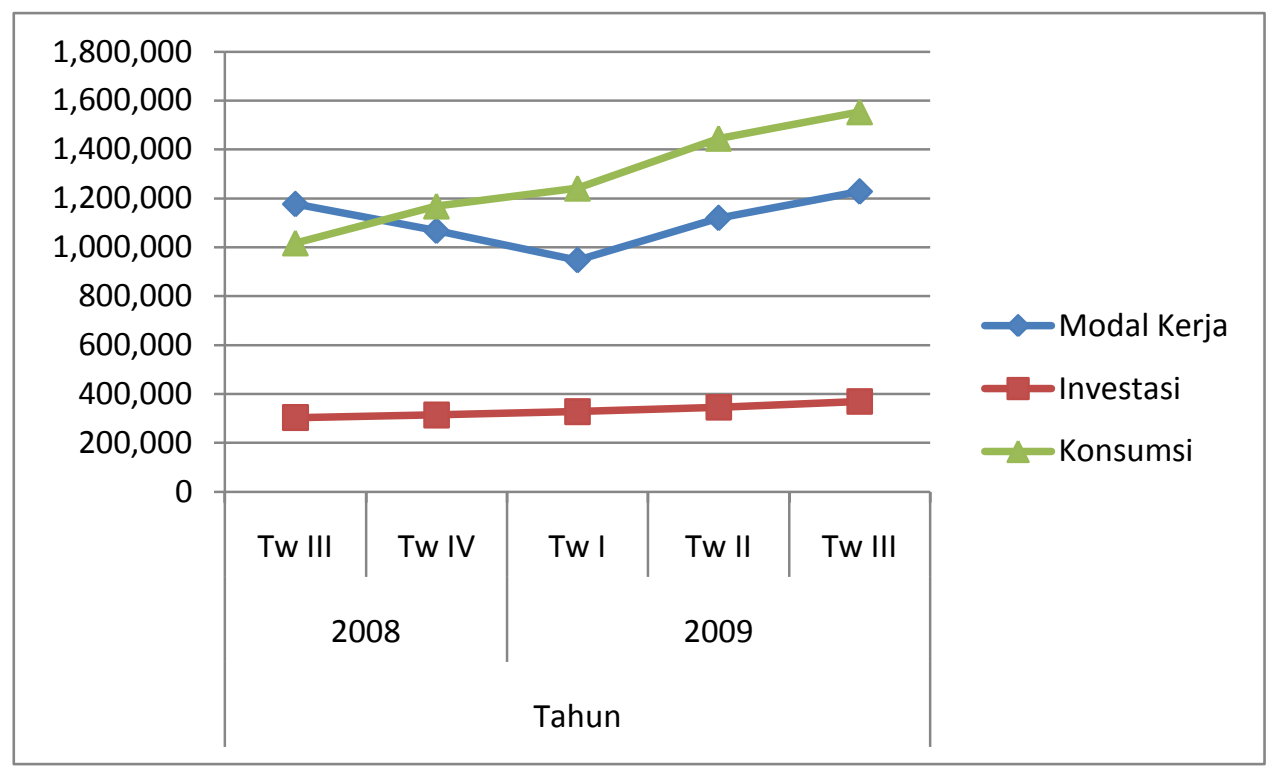

Gambar 4. Perkembangan Modal Kerja, Investasi, dan Konsumsi

Periode triwulan III 2008 - triwulan III 2009 (dalam satuan jutaan)

Sumber : Kajian Ekonomi Regional Jawa Timur Triwulan III-2009, data diolah

Perkembangan pembiayaan

Perbankan Syariah di provinsi Jawa Timur cukup baik meskipun untuk sekian kalinya menyatakan bahwa perkembangannya sangat lambat. Dari Gambar diatas bisa dilihat bahwa grafik Investasi dan Konsumsi dari Tw III 2008- Tw 2009 terus berkembang kecuali pada grafik Modal kerja yang pada Tw IV 2008 - Tw I 2009 mengalami penurunan, yakni pada Tw IV 2008 sebesar Rp. 1,067 triliun dan Tw I 2009 sebesar Rp. 947,447 juta.

Pada penyaluran dana dikenal beberapa jenis pembiayaan. Bila dilihat dari sifat penggunaannya maka pembiayaan dibagi menjadi pembiayaan produktif dan konsumtif. Pada grafik diatas menunjukkan bahwa pembiayaan konsumtif lebih tinggi dari pada pembiayaan lainnya yakni modal kerja serta investasi. Bagi orang awam akan langsung mendefinisikan bahwa Perbankan Syariah di Jawa Timur belum melakukan perannya secara maksimal, disebabkan pembiayaan yang diberikan bukannya menumbuhkan sektor rill namun lebih cenderung memberikan pembiayaan kepada sektor konsumsi. Seperti yang terpapar pada grafik dibawah ini:

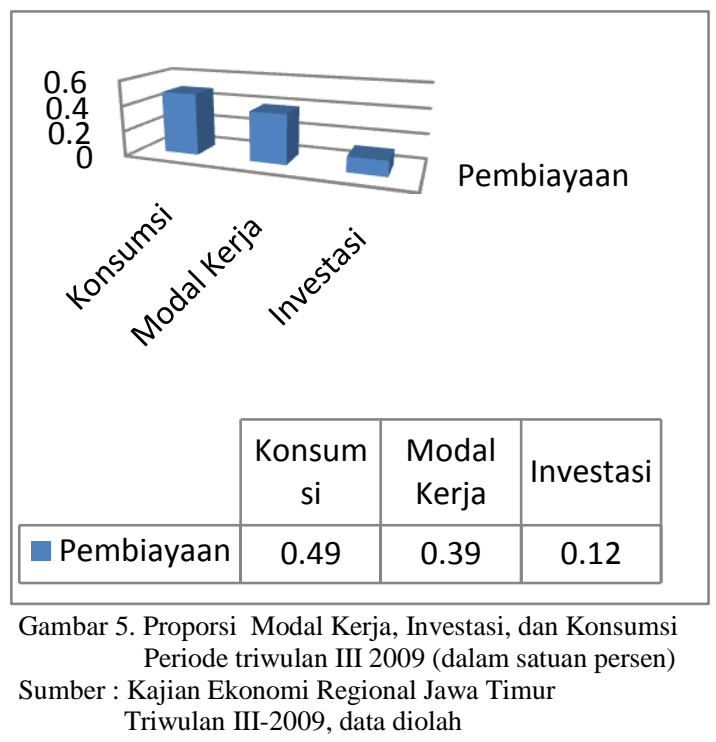

Hal ini perlu diluruskan karena sesungguhnya pembiayaan produktif adalah penggabungan antara pembiayaan modal kerja dan investasi sehingga presentase yang lebih mendominasi antara pembiayaan konsumtif dan produktif belum bisa diputuskan sebelum penjumlahan antara pembiayaan Investasi dan modal kerja dilakukan. 
Maka penjumlahan tersebut secara jelas tergambar pada diagram dibawah ini :

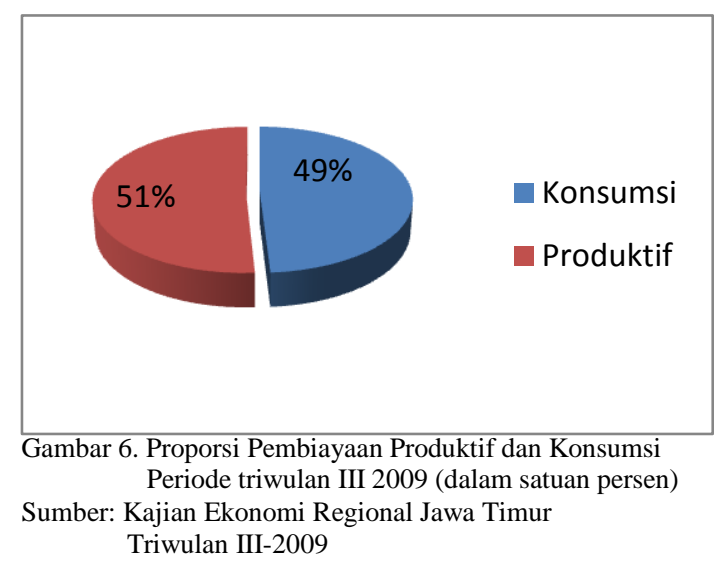

Dari data diatas dapat diketahui bahwa untuk periode triwulan III 2009. Penyaluran dana/pembiayaan yang diberikan oleh Perbankan Syariah di Jawa Timur lebih besar kepada pembiayaan produktif sebesar $51 \%$ dibanding dengan pembiayaan konsumsi sebesar $49 \%$. Triwulan sebelumnya juga demikian yakni Tw III 2008 perbandingan presentase antara Produktif dan Konsumsi yakni 59\% : 41\%, Tw IV 2008 sebesar 54\%: $46 \%$, Tw I 2009, 51\%: 49\% dan pada Tw II 2009 posisi seimbang yakni 50\% : 50\%.

Melihat data diatas, Perbankan Syariah juga tidak bisa berpuas diri karena perbedaan presentasi antara kedua pembiayaan juga sangat tipis. Asumsi dari peneliti melihat kondisi sekarang ini masyarakat Indonesia sedang dilanda budaya konsumtif. Menyikapi hal tersebut, peran Perbankan Syariah dalam pertumbuhan perekonomian rakyat harus kembali lagi memfokuskan diri dengan memberikan pembiayaan kepada sektor produktif, bukan konsumtif. padahal Islam mengajarkan melalui contoh suri tauladan yakni Rasulullah Saw. Pada zamannya masyarakat muslim terbiasa hidup sederhana dan tidak melakukan praktik konsumsi yang mencolok. Karena itu, tidak ada alasan meminjam dana untuk tujuan pamer diri atau untuk keperluan konsumsi yang tidak penting.

Pembahasan diatas adalah mengenai pembiayaan bila ditinjau dari sifat penggunaannya, ternyata selain jenis tersebut pembiayaan juga dibagi menurut sektor ekonomi. Menurut BI (2009) di Jawa Timur memiliki empat sektor utama yakni Sektor PHR/ hotel dan restoran, sektor Pertanian, Sektor Industri dan sektor Angkut/ Komunikasi, pada kesempatan kali ini akan membahas mengenai peran perbankan dalam hal ini pemberian pembiayaan kepada sektor ekonomi yang ada di Jawa Timur. Gambaran perkembangan pemberian Pembiayaan kepada sektor ekonomi akan terpapar pada gambar 7.

Pada penyaluran pembiayaan Perbankan Syariah ternyata keempat sektor utama yang berada di Jawa Timur yakni Sektor PHR/ hotel dan restoran, sektor Pertanian, Sektor Industri dan sektor Angkut/ Komunikasi masih belum diperhatikan. Asumsi peneliti bahwa bisa saja keempat sektor tersebut diberikan pembiayaan oleh bank konvesional, dan belum menggunakan jasa Perbankan Syariah.

Dari sektor ekonomi yang ada, ternyata sektor yang mendominasi mendapatkan pembiayaan yakni sektor lain- lain, dengan jumlah pembiayaan pada Tw III 2009 sebesar Rp. 1,553 triliun. Sektor lain- lain sektor yang tidak termaksud dalam sektor ekonomi yang tersebut diatas, bila dicontohkan sektor ekonomi tersebut yaitu dari pembiayaan konsumsi. Perihal pembiayaan yang lebih cenderung diberikan kepada sektor konsumsi, harus terus dievaluasi, karena tidak sesuai dengan ajaran Islam dan juga secara tidak langsung membiarkan dan mendukung budaya konsumtif untuk tetap tercirikan di masyarakat Indonesia, apalagi masyarakat Indonesia mayoritas beragama Islam. 


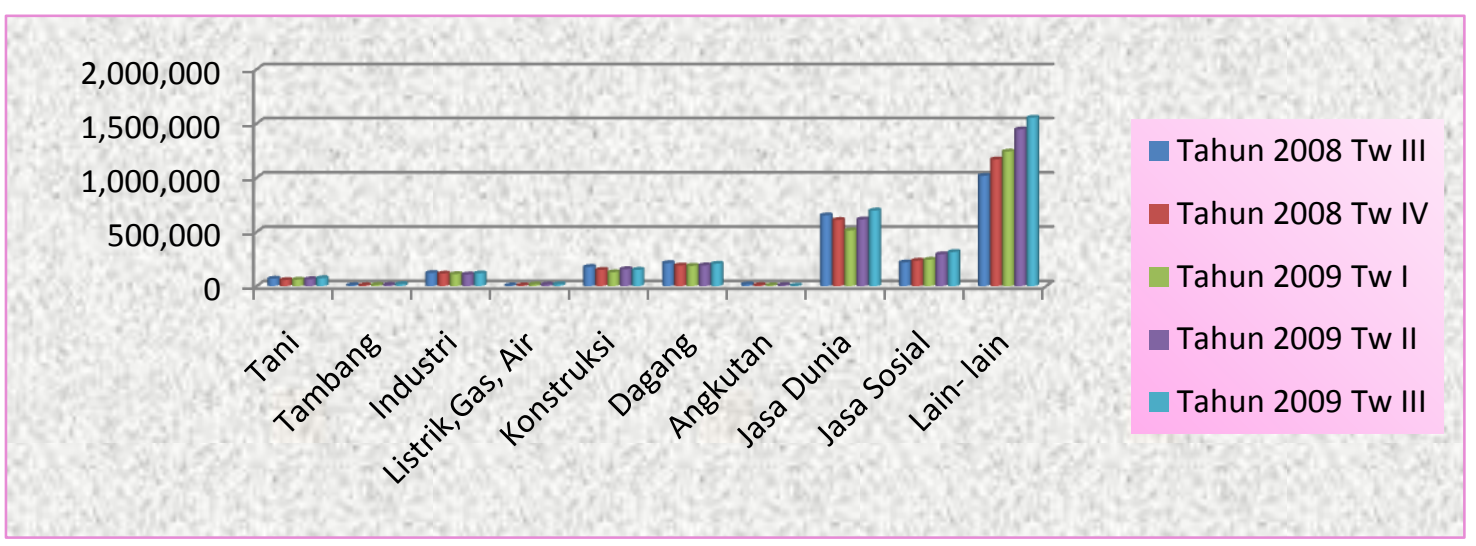

Gambar 7. Perkembangan Pembiayaan Pada Sektor Ekonomi

Periode triwulan III 2008 - triwulan III 2009 (dalam satuan jutaan)

Sumber: Kajian Ekonomi Regional Jawa Timur Triwulan III-2009, data diolah

Perlu diperhatikan bahwa Perbankan Syariah adalah turunan dari syariat Islam. Syariah yang dimaksud bukan saja menyeluruh (syumul) yang mana Islam merangkum seluruh aspek kehidupan baik ibadah maupun muamalah (sosial), tetapi juga universal yang dapat diterapkan setiap tempat dan waktu bahkan sampai akhir nanti.

Urutan kedua berada pada sektor Jasa Dunia, yang termaksud didalamnya yaitu Pertama, Real Estate yang menangani mengenai pembangunan gedung, fkat, rumah, kosan, dan sebagainya. Kedua, Profesi selain dokter, yaitu pengacara, notaris,akuntan, insinyur dan jasa- jasa individual lainnya. Ketiga, Leasing, asuransi, agen, dan sebagainya.

Pada sektor ini Perbankan Syariah memberikan pembiayaan pada Tw III 2009 sebesar Rp. 697 juta dan yang paling menarik yaitu ternyata sektor yang paling kecil diberikan pembiayaan yakni sektor angkutan yang mana salah satu sebagai empat sektor terbesar di Jawa Timur. Sektor Angkutan dibiaya hanya sebesar Rp. 4,475 Juta. Selain itu yang harus diperhatikan bahwa Jawa
Timur adalah kota Industri maka para perusahaan pembiayaan seharusnya lebih memperhatikan sektor ini, karena bagaimanpun sektor industri memiliki peran yang cukup besar dalam pertumbuhan ekonomi di Jawa Timur, dan sektor ini pada Tw III 2009 diberikan pembiayaan sebesar Rp. 117,756 juta. Sektor lain yang tidak kalah pentingnya yang harus diperhatikan yakni sektor pertanian. Bagaimanpun sektor ini juga termaksud empat sektor terbesar di Jawa Timur dan pada Tw III 2009 Perbankan Syariah memberikan pembiayaan sebesar Rp. 72,932 juta lebih kecil daripada sektor industri. Bila diproporsikan maka akan terpapar seperti gambar dibawah ini:

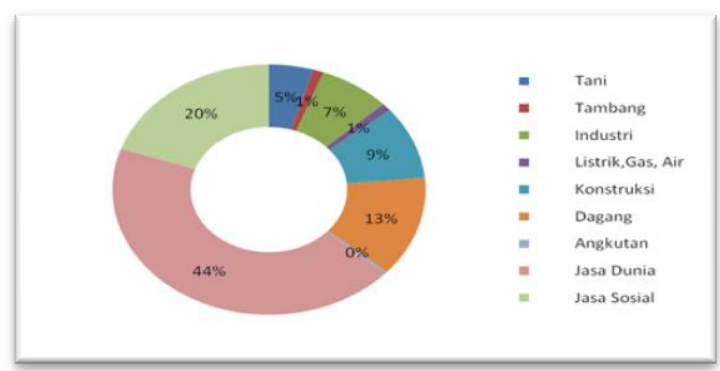

Gambar 8. Proporsi Pembiayaan Pada Sektor Ekonomi Periode Triwulan III 2009 (dalam satuan persen) Sumber : Kajian Ekonomi Regional Jawa Timur Triwulan III-2009, data diolah 
Tabel 2. Metode Perhitungan Proyeksi Fungsi Intermediasi

\begin{tabular}{|c|c|c|c|}
\hline Periode & $X$ & $\mathrm{Y}^{*}$ & \\
\hline 2008 : Tw III & 0 & 3.014 .199 & \multirow{2}{*}{$\bar{Y}=\frac{6.286 .027}{2}=3.143 .013,5$} \\
\hline 2008 : Tw IV & 1 & 3.271 .828 & \\
\hline 2009 : Tw I & 2 & 3.631 .656 & \multirow{3}{*}{$\bar{Y}=\frac{8.648 .219}{2}=4.324 .109,5$} \\
\hline 2009 : Tw II & 3 & 4.278 .696 & \\
\hline 2009 : Tw III & 4 & 4.369 .523 & \\
\hline
\end{tabular}

Dari data yang ada maka adapun perhitungan Proyeksi atau Tren Perkembangan Fungsi Intermediasi Perbankan Syariah Pada Periode Triwulan IV 2009 - Triwulan IV 2010, akan diolah sesuai dengan rumus yang ada. Analisis data adalah sebagai berikut:

Tabel 3. Perkembangan Total Aset Perbankan Syariah Periode Triwulan III 2008 - Triwulan III 2009 (dalam sa tuan jutaan)

\begin{tabular}{cl}
\hline Periode & Total Aset \\
\hline $2008:$ Tw III & 3.014 .199 \\
$2008:$ Tw IV & 3.271 .828 \\
$2009:$ Tw I & 3.631 .656 \\
$2009:$ Tw II & 4.278 .696 \\
$2009:$ Tw III & 4.369 .523 \\
\hline
\end{tabular}

Sumber : Kajian Ekonomi Regional Jawa Timur Triwulan III-2009

Adapun penyelesaiannya adalah sebagaimana pada tabel 2 .

Berdasarkan perhitungan diperoleh dua titik koordinat $\{(0,5)$, $(3.143 .013,5)\} \quad$ dan $\quad\{(3,5)$, $(4.324 .109,5)\}$. Kemudian nilai- nilai ini dimasukkan kedalam persamaan $\mathrm{Y}=\mathrm{a}+\mathrm{bX}$, sebagai berikut :

3.143.013,5 $=\mathrm{a}+\mathrm{b}(0,5)$

$4.324 .109,5=a+b(3,5)$

Dari persamaan (1)

$\mathrm{a}=3.143 .013,5-0,5 \mathrm{~b}$, masukkan ke (2) $4.324 .109,5=3.143 .013,5-0,5 b+3,5 b$ $4.324 .109,5=3.143 .013,5-3 b$

$$
\begin{aligned}
3 b & =4.324 .109,5-3.143 .013,5 \\
3 b & =1.181 .096 \\
b & =393.698,67 \\
a & =3.143 .013,5-0,5(393.698,67) \\
a & =2.946 .164,165
\end{aligned}
$$

Sehingga $Y=2.946 .164,165+$ 393.698,67 X (variabel waktu)

Dari persamaan diatas dapat diramalkan Total aset triwulan I tahun 2010 adalah sebagai berikut :

$$
\begin{aligned}
& \text { Total Aset } \\
& \begin{array}{l}
\mathrm{Y}=2.946 .164,165+393.698,67(5) \\
\quad \mathrm{Y}=4.914 .657,52
\end{array}
\end{aligned}
$$

Dengan cara yang sama untuk Tw I 2010- Tw IV 2010. Dengan demikian, proyeksi perkembangan Total aset dalam waktu lima triwulan mendatang apabila tidak dipengaruhi oleh gejolak ekonomi dan sebagainya diperkirakan akan berkembang menjadi:

Tabel 4. Perkiraan Total Aset Perbankan Syariah Periode Triwulan IV 2009 - Triwulan IV 2010 (dalam satuan jutaan)

\begin{tabular}{cc}
\hline Periode & Total Aset \\
\hline Tw IV 2009 & $4.914 .657,52$ \\
Tw I 2010 & $5.308 .356,19$ \\
Tw II 2010 & $5.702 .054,86$ \\
Tw III 2010 & $6.095 .753,53$ \\
Tw IV 2010 & $6.489 .452,20$ \\
\hline
\end{tabular}


Tabel 5. Perkembangan DPK dan Pembiayaan Perbankan Syariah Periode Triwulan III 2008 Triwulan III 2009 (dalam satuan jutaan)

\begin{tabular}{ccc}
\hline Periode & DPK & Pembiayaan \\
\hline $2008:$ Tw III & 2.155 .819 & 2.497 .399 \\
$2008:$ Tw IV & 2.527 .041 & 2.549 .316 \\
$2009:$ Tw I & 2.959 .175 & 2.516 .204 \\
2009: Tw II & 3.507 .543 & 2.909 .754 \\
$2009:$ Tw III & 3.558 .948 & 3.151 .113 \\
\hline
\end{tabular}

Sumber : Kajian Ekonomi Regional Jawa Timur Triwulan III-2009

Dengan cara yang sama seperti pada perhitungan trend Total Aset, maka akan diperoleh proyeksi perkembangan tambahan DPK dan pembiayaan untuk lima triwulan mendatang sebagai berikut:
Tabel 6. Perkiraan DPK dan Pembiayaan Perbankan Syariah Periode Triwulan IV 2009 Triwulan IV 2010 (dalam satuan jutaan)

\begin{tabular}{ccc}
\hline Periode & DPK & Pembiayaan \\
\hline Tw IV 2009 & 4.129 .154 & $3.283 .971,85$ \\
Tw I 2010 & 4.526 .426 & $3.452 .997,15$ \\
Tw II 2010 & 4.923 .698 & $3.622 .022,45$ \\
Tw III 2010 & 5.320 .970 & $3.791 .047,75$ \\
Tw IV 2010 & 5.718 .242 & $3.960 .073,05$ \\
\hline
\end{tabular}

Pada pembahasan diatas telah memperoleh hasil perhitungan trend/ proyeksi dari Total Aset, DPK dan pembiayaan secara keseluruhan. Pada kesempatan sekarang ini akan dilakukan perhitungan mengenai trend/ proyeksi secara terperinci mengenai DPK dan Pembiayaan. DPK yang terdiri dari giro, tabungan dan deposito serta pembiayaan yang terdiri dari pembiayaan Produktif (Modal Kerja dan Investasi) dan konsumtif serta pembiayaan dilihat dari sektor ekonomi.

Tabel 7. Perkembangan Modal Kerja, Investasi, Konsumsi

Periode Triwulan III 2008 - Triwulan III 2009 (dalam satuan jutaan)

\begin{tabular}{cccccc}
\hline \multirow{2}{*}{ Pembiayaan } & TW III & TW IV & Periode & & \\
& 2008 & 2008 & TW I 2009 & TW II & TW III \\
& 1.176 .759 & 1.067 .224 & 947.447 & 1.119 .938 & 1.228 .292 \\
Modal kerja & 303.363 & 313.971 & 327.589 & 344.810 & 369.503 \\
Investasi & 1.017 .277 & 1.168 .121 & 1.241 .168 & 1.445 .006 & 1.553 .318 \\
\hline Konsumsi &
\end{tabular}

Sumber : Kajian Ekonomi Regional Jawa Timur Triwulan III 2009 
Tabel 8. Perkembangan Pembiayaan di Sektor Ekonomi Periode Triwulan III 2008 - Triwulan III 2009 (dalam satuan jutaan)

\begin{tabular}{cccccc}
\hline \multirow{2}{*}{ Per Sektor Ekonomi } & \multicolumn{5}{c}{ Periode } \\
& TW III & TW IV & TW I & TW II & TW III \\
\hline Tani & 68.578 & 56.389 & 59.316 & 64.014 & 72.932 \\
Tambang & 8.339 & 8.149 & 11.367 & 11.275 & 17.695 \\
Industri & 120.819 & 115.554 & 110.431 & 107.429 & 117.756 \\
Listrik,Gas, Air & 6.749 & 7.754 & 15.326 & 14.855 & 16.287 \\
Konstruksi & 176.659 & 149.609 & 127.262 & 156.687 & 150.489 \\
Dagang & 212.205 & 189.991 & 186.910 & 191.828 & 206.648 \\
Angkutan & 15.781 & 9.083 & 7.772 & 9.358 & 4.475 \\
Jasa Dunia & 652.870 & 610.155 & 513.321 & 615.166 & 697.150 \\
Jasa Sosial & 218.122 & 234.511 & 243.331 & 294.136 & 314.363 \\
Lain- lain & 1.017 .277 & 1.168 .121 & 1.241 .168 & 1.445 .006 & 1.553 .318 \\
\hline
\end{tabular}

Sumber : Kajian Ekonomi Regional Jawa Timur Triwulan III 2009

Dengan cara yang sama seperti pada perhitungan trend Total Aset, maka akan diperoleh proyeksi perkembangan tambahan DPK dan pembiayaan untuk lima triwulan mendatang sebagai berikut:

Tabel 9. Perkiraan Giro, Tabungan dan Deposito

Periode Triwulan IV 2009 - Triwulan IV 2010 (dalam satuan jutaan)

\begin{tabular}{cccc}
\hline Periode & Giro & DPK \\
Tabungan & Deposito \\
\hline Tw IV 2009 & $480.965,52$ & $1.344 .710,25$ & $2.299 .977,48$ \\
Tw I 2010 & $525.336,19$ & $1.421 .281,75$ & $2.573 .973,81$ \\
Tw II 2010 & $569.706,86$ & $1.497 .853,25$ & $2.847 .970,14$ \\
Tw III 2010 & $614.077,53$ & $1.574 .424,75$ & $3.121 .966,47$ \\
Tw IV 2010 & $658.448,20$ & $1.650 .996,25$ & $3.395 .962,80$ \\
\hline
\end{tabular}

Tabel 10. Perkiraan Modal Kerja, Investasi, Konsumsi

Periode Triwulan IV 2009 - Triwulan IV 2010 (dalam satuan jutaan)

\begin{tabular}{cccc}
\hline Periode & Modal Kerja & $\begin{array}{c}\text { DPK } \\
\text { Investasi }\end{array}$ & Konsumsi \\
\hline Tw IV 2009 & $1.200 .176,49$ & $381.401,27$ & $1.702 .393,52$ \\
Tw I 2010 & $1.217 .550,82$ & $397.564,44$ & $1.837 .881,19$ \\
Tw II 2010 & $1.234 .925,15$ & $413.727,61$ & $1.973 .368,86$ \\
Tw III 2010 & $1.252 .299,48$ & $429.890,78$ & $2.108 .856,53$ \\
Tw IV 2010 & $1.269 .673,81$ & $446.053,95$ & $2.244 .344,20$ \\
\hline
\end{tabular}


Tabel 11. Perkiraan Pembiayaan di Sektor Ekonomi Periode Triwulan IV 2009 - Triwulan IV 2010 (dalam satuan jutaan)

\begin{tabular}{lrrrrr}
\hline \multicolumn{1}{c}{\begin{tabular}{c} 
Per Sektor \\
\multicolumn{1}{c}{ Ekonomi }
\end{tabular}} & \multicolumn{1}{c}{ 2009 } & \multicolumn{5}{c}{ Periode } \\
\multicolumn{1}{c}{ TW IV } & \multicolumn{1}{c}{ TW I } & \multicolumn{1}{c}{ TW II } & \multicolumn{1}{c}{ TW III } & \multicolumn{1}{c}{ TW IV } \\
\hline Tani & $71.467,75$ & $73.464,25$ & $75.460,75$ & $77.457,25$ & $79.453,75$ \\
Tambang & $17.605,49$ & $19.685,82$ & $21.766,15$ & $23.846,48$ & $25.926,81$ \\
Industri & $109.795,49$ & $107.930,82$ & $106.066,15$ & $104.201,48$ & $102,336,81$ \\
Listrik,Gas, Air & $19.730,77$ & $22.503,94$ & $25.277,11$ & $28.050,28$ & $30.823,45$ \\
Konstruksi & 148.815 & 145.633 & 142.451 & 139.269 & 136.087 \\
Dagang & 198.308 & 197.688 & 197.068 & 196.448 & 195.828 \\
Angkutan & $4.158,75$ & $2.320,25$ & 481,75 & $-1.356,75$ & $-3.195,25$ \\
Jasa Dunia & $668.480,77$ & $676.695,94$ & $684.911,11$ & $693.126,28$ & $701.341,45$ \\
Jasa Sosial & $343.216,02$ & $369.193,69$ & $395.171,36$ & $421.149,03$ & $447.126,70$ \\
Lain- lain & $1.702 .393,52$ & $1.837 .881,19$ & $1.973 .368,86$ & $2.108 .856,53$ & $2.244 .344,20$ \\
\hline
\end{tabular}

Adapun asumsi - asumsi yang digunakan yaitu: 1. Perbankan Syariah semakin dikenal karena bukan untuk umat Islam saja namun semua agama, dan lapisan masyarakat; 2. Permintaan Produk dan penggunaan jasa Perbankan Syariah meningkat; 3. Intensitas penghimpunan dan pembiayaan dana meningkat; 4. Pembiayaan kepada sektor rill difokuskan kepada pembiayaan produktif; 5. Penyaluran pembiayaan kepada 4 sektor utama yakni Sektor PHR/ hotel dan restoran, sektor Pertanian, Sektor Industri dan sektor Angkut/ Komunikasi; 6. Aset Perbankan Syariah tumbuh meningkat; 7. Perekonomian Indonesia semakin membaik paska krisis ekonomi 2009; 8. Pertambahan penduduk sebesar kurang lebih $2 \%$ setiap tahunnya; dan 9 . Peningkatan pendapatan per kapita penduduk dianggap naik sejalan dengan membaiknya perekonomian Indonesia.

\section{PENUTUP}

Kondisi perkembangan Total Aset, DPK cenderung lambat, yakni pada Tw III 2008 - Tw III 2009 pertumbuhannya rata- rata $2 \%-5 \%$ sedangkan pembiayaan sangat fluktuatif, yakni dari $2 \%$ turun menjadi $(-1 \%)$ dan tumbuh dengan cepat sebesar $16 \%$ dan akhir Tw III 2009 kembali turun dengan pertumbuhan $8 \%$.
Dalam penghimpunan dana dikenal 3 bentuk yakni giro, tabungan dan deposito. Perkembangan ketiga bentuk DPK cenderung lambat dan fluktitif dan yang paling diminati oleh masyarakat sampai akhir Tw III 2009 yakni Deposito dengan $58 \%$.

Fungsi intermediasi Perbankan Syariah yang lain selain menghimpun dana yakni menyalurkan dana atau dalam Perbankan Syariah dikenal dengan nama pembiayaan. Dalam hal ini pembiayaan yang diberikan kepada masyarakat dikenal pembiayaan produktif dan konsumtif. Proporsi keduanya sampai periode Tw III 2009 lebih besar diberikan kepada pembiayaan produktif dengan presentase $51 \%$ dan pembiayaan konsumtif $49 \%$.

Apabila pembiayaan ditinjau dari penggunaannya maka dibagi menurut sektor ekonomi. Dari sektor ekonomi yang ada, yang mendominasi mendapatkan pembiayaan yakni sektor lain- lain dengan total pembiayaan sebesar Rp. 1,553 triliun, sektor lainlain disini yakni sektor ekonomi dari pembiayaan konsumsi. Dan apabila dilihat dari sektor ekonomi diluar pembiayaan konsumsi maka sektor jasa dunia yang memperoleh pembiayaan terbesar hingga akhir Tw III 2009 sebesar Rp. 697 juta dan yang paling rendah dibiayai yakni sektor angkutan 
sebesar Rp. 4,475 juta. Yang mana sektor angkutan merupakan salah satu dari empat sektor terbesar di Jawa Timur.

Maka bila melihat data pemberian pembiayaan kepada sektor ekonomi yang ada di Jawa Timur, Perbankan Syariah belum memberikan perhatian yang khusus dalam pemberiaan pembiayaan bagi 4 sektor terbesar dan unggulan di Jawa Timur yakni Sektor PHR, hoteldan restoran, sektor pertanian, sektor industri dan sektor angkut/ komunikasi.

Proyeksi atau trend perkembangan fungsi Intermediasi setiap triwulannya semakin berkembang, ada beberapa yang cenderung perkembangannya menurun, yakni pemberian pembiayaan bila dilihat dari sektor ekonomi. Adapun sektor tersebut adalah Industri, Konstruksi, Dagang, dan Angkutan. Namun ini hanya proyeksi karena semua dapat berubah sewaktu- waktu sesuai dengan adanya gejolak ekonomi yang terjadi.

Oleh karena itu, untuk mematangkan fungsi intermediasi Perbankan Syariah harus lebih melancarkan lagi promosi bisa melalui seminar, talk show, penyuluhan, iklan dan sebagainya agar masyarakat bisa lebih kenal dan dekat dengan Bank Syariah atau Lembaga Keuangan Syariah sehingga ada keinginan untuk menggunakan jasa, produk Bank Syariah.

Selain itu harus menghilangkan image "Perbankan Syariah hanya untuk umat Islam" dan sebagai Lembaga keuangan yang berlandaskan Syariah harus kembali mengfokuskan diri untuk memberikan pembiayaan pada sektor produktif sehingga dapat menumbuhkan sektor rill, serta meningkatkan pemberian pembiayaan kepada empat sektor utama yang berada di Jawa Timur karena keempat sektor tersebut yang menggerakkan perekonomian Jawa Timur.

\section{DAFTAR PUSTAKA}

Ali Sakti 2009, "Sharia Economics Activities 4". Bank Indonesia. Jakarta

Antonio, M.S., 2001, Bank syariah dari teori ke praktek, Gema Insani Press. Jakarta

Hariati, Henro Yudi, 2008, Analisa Perkembangan Perbankan Syariah di Jawa Timur Selama Masa Krisis Ekonmi di Indonesia Periode 1997-2003.

Haritsi, J.A., 2006, Fikih EkonomiUmar bin Al-Khathab, Khalifa. Jakarta Timur

Muhammad, 2002, Manajemen Bank Syariah, UPP AMP YKPN, Yogyakarta.

Rivai,V., Veithzal, A.P., 2008, Islamic Financial Management, PT RajaGrafindo Persada. Jakarta Utara

Supranto, J., 2000, Statisti "Teori dan Aplikasi" Erlangga. Jakarta

Siamat, D., 2005, "Manajemen Lembaga Keuangan”, FE UI. Jakarta

Saeed, A., 2003, Bank Islam dan bunga, Pustaka pelajar. Yogyakarta

Sugiyono, 2009, Metode Penelitian Administrasi, alfabeta. Bandung

Waluyo, D. E., 2006, Ekonomika Makro, UMM press. Malang. 
www.BI.com Peraturan Bank Indonesia Nomor : 62/24/PBI/2004, akses 1 desember 2009

www.kabarbisnis.com. "Bank syariah lebih nayak biaya sektor konsumtif'.Juni,15,2009

www.kapanlagi.com “ Pertumbuhan ekonomi jawa timur lebih tinggi dari perkiraan" Mei, 15, 2009.

www.wordprees.com "Perbandingan antara pembiayaan produktif dan konsumtif yang dikaitkan dengan NPF pada BPRS di NAD" akses tanggal 11 November 2009" 